\begin{tabular}{|l|l|l|l|l|}
\hline ACTA CARSOLOGICA & $32 / 2$ & 20 & $244-254$ & LJUBLJANA 2003 \\
\hline
\end{tabular}

COBISS: 1.01

\title{
KARST SPRINGS OF ALASHTAR, IRAN
}

\author{
KRAŠKI IZVIRI ALAŠTAR, IRAN
}

MOHAMAD REZA AHMADIPOUR ${ }^{1}$

${ }^{1}$ Associated Professor, Department of Geology, Lorestan University, Iran.

Fax: +98- 661-22782, Email: ahmadipour_mr@yahoo.com

Prejeto / received: 8. 7. 2003 


\section{Abstract \\ Mohamad Reza Ahmadipour: Karst Springs of Alashtar, Iran}

UDC: $556.3(55)$

Alashtar area is situated in the western part of Iran. The Jurassic Cretaceous dolomitic limestone covers most of the area. There are 5 karstic springs named as Amir, Chenare, Zaz, Honam and Papi. All the springs except the Papi emerge from the Jurassic-Cretaceous limestone.The Papi Spring discharges at the contact of the Jurassic-Cretaceous and the Marly limestone of Eocene age. The springs show variation of discharge during the different periods. Faults and the lineaments are the main avenues for the emergence of the springs. The springs are responsible for the rivers in the plain. The fractures are classified as thrust and normal faults. The faults are mostly formed at the junction of the surrounding carbonate rocks which give a graben structure to the plain. The springs have an important role in recharging the plain. It is due to the fractures and the springs that the plain aquifer has a high potential of water. The discharge of some of the wells is more than 60 l/s. The discharge of the springs varies considerably during the year. Out of these, the Amir , Chenare and Honam springs are considered as permanent springs. The annual discharge of the springs is $111 \mathrm{MCM}$. The hydrochemical analyses of the springs show that all of them are of carbonate type.

Key words: karst hydrology, karst spring, Alashtar, Iran.

Izvleček

UDK: 556.3(55)

\section{Mohamad Reza Ahmadipour: Kraški izviri Alaštar, Iran}

Področje Alaštar je v zahodnem delu Irana. Večji del ozemlja je iz jursko-krednih dolomitov in apnencev. Tam je pet kraških izvirov: Amir, Čenare, Zaz, Honam in Papi. Vsi izviri, razen Papija, so v jursko-krednih apnencih. Izvir Papi je na stiku jursko-krednih apnencev z lapornatimi apnenci eocenske starosti. Glavne -ile, ki dovajajo vodo izvirom, so prelomi in tektonske linije. Ti izviri so razlog, da po ravnini tečejo reke. Prelome lahko razdelimo v narive in normalne prelome. Prelomi se najčešče javljajo na stiku apnencev z ravnino, v čemer je vzrok, da ima ta strukturo tektonskega jarka. Izviri igrajo veliko vlogo pri napajanju ravnine. Zaradi prelomov in izvirov ima ravninski vodonosnik veliko vode. Tako dajejo nekatere vrtine preko 601 vode v sekundi. Pretoki izvirov se preko leta precej spreminjajo. Vseeno uvrščajo izvire Amir, Čenare in Honam med stalne izvire. Skupna letna količina vode je 111 milijonov $\mathrm{m}^{3}$. Hidrokemične analize ka•ejo, da so vsi izviri karbonatnega tipa.

Ključne besede: hidrologija krasa, kraški izvir, Alaštar, Iran. 


\section{INTRODUCTION}

The area under study with mean annual rainfall of $500 \mathrm{~mm}$ is situated in the Zagros Zone, north of the Lorestan province (west of Iran). The catchment area is a 745 square kilometers.

\section{GEOLOGY}

Most of the area consists of carbonate rocks of the Jurassic-Cretaceous dolomitic limestone and the malry limestone of Eocene. The Jaurassic- Cretaceous rocks (Jk) cover most of the area. Due to the development of the fractures and the joints, karstic springs have emerged. The marly limestone lies unconformably on the Jurassic-Cretaceous rocks and acts as an impervious formation at the outlet of the plain. The general geology and liniaments and a view of the jurassic - cretaceous limeston (North west) of the area are shown in figures 1, 2 and 3.

\section{WATER RESOURCES}

Water resources of the area include rivers, wells, karstic springs and Qanats. The most important river in the area is the Kahman river that receives most of its flow from the Jurassic-Cretaceous rocks in the northern part. The river passes through the plain and has an important role in recharging the groundwater aquifer. The mean annual discharge of the river is 118 million $\mathrm{m}^{3}$. The Kahman river and the Honam river (south-west) of the area, at the outlet of the plain join each other and constitute the Du-ab river.The total annual discharge of the river is 236 million $\mathrm{m}^{3}$.

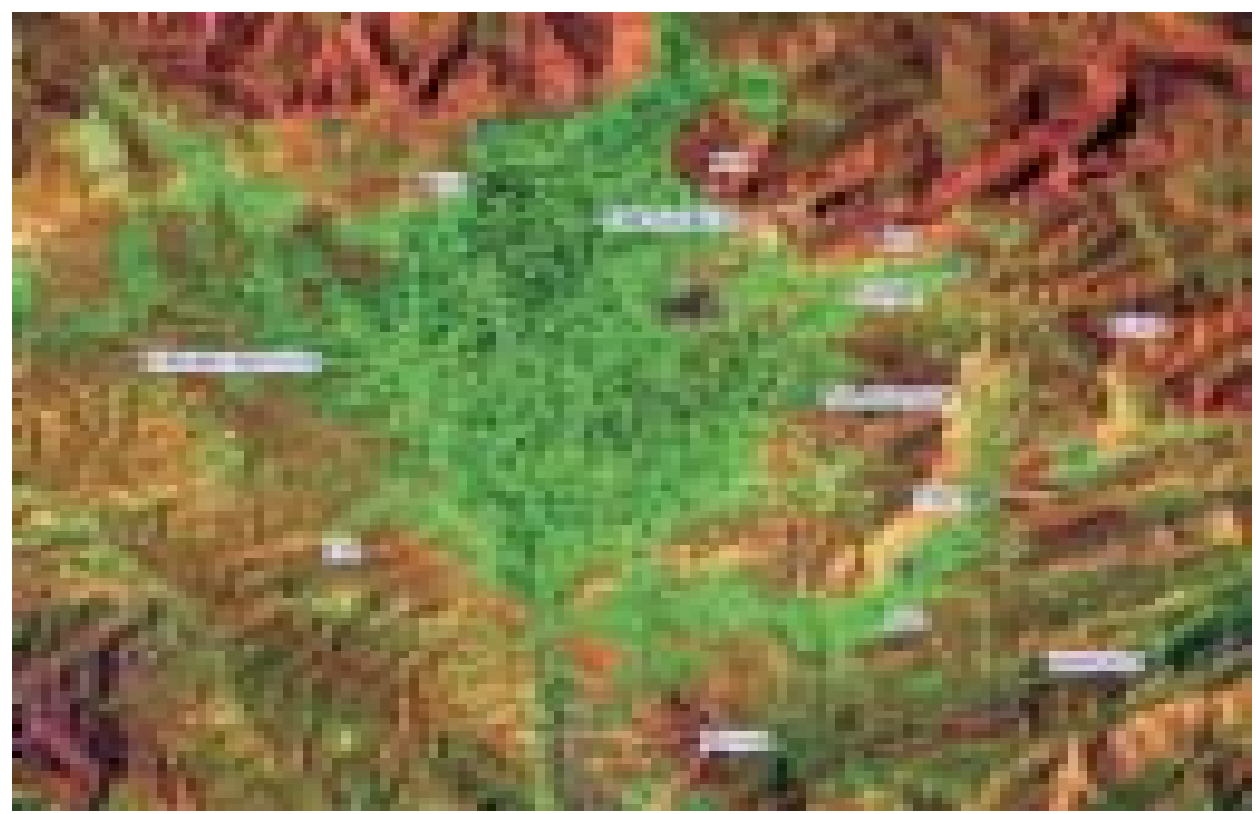

Fig. 1: General geology and the location of the springs. 


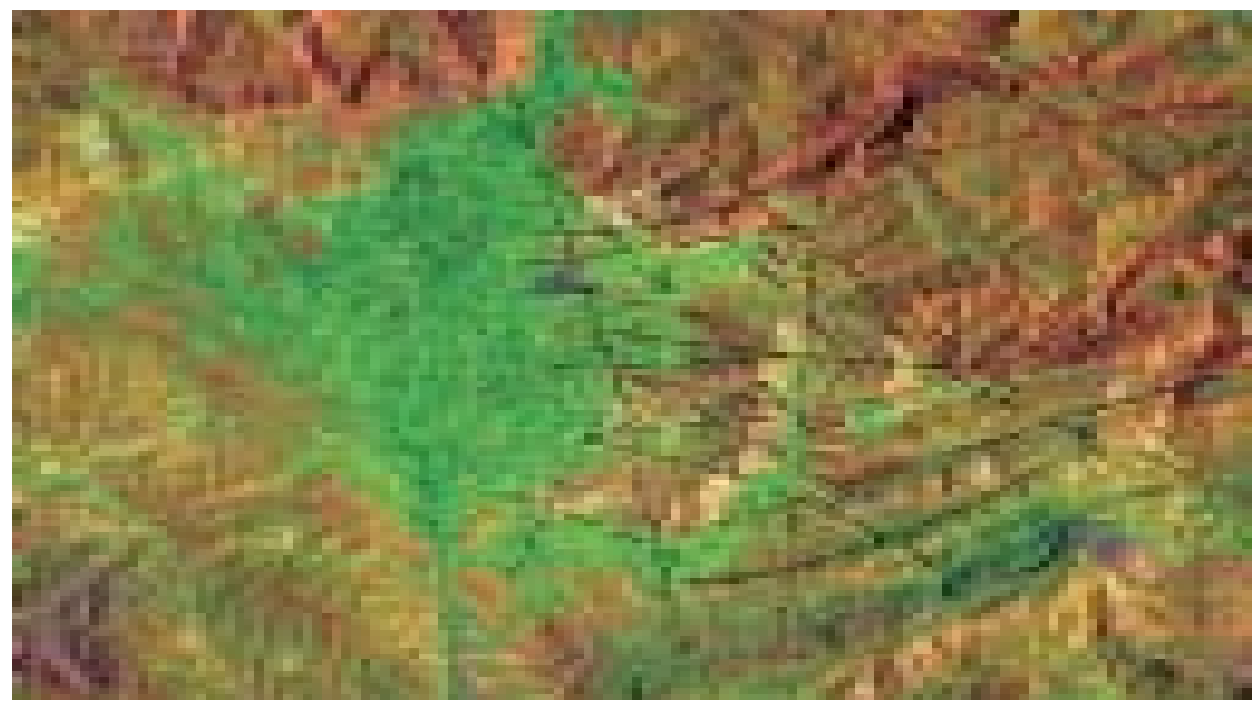

Fig. 2: Faults and lineaments of the area.

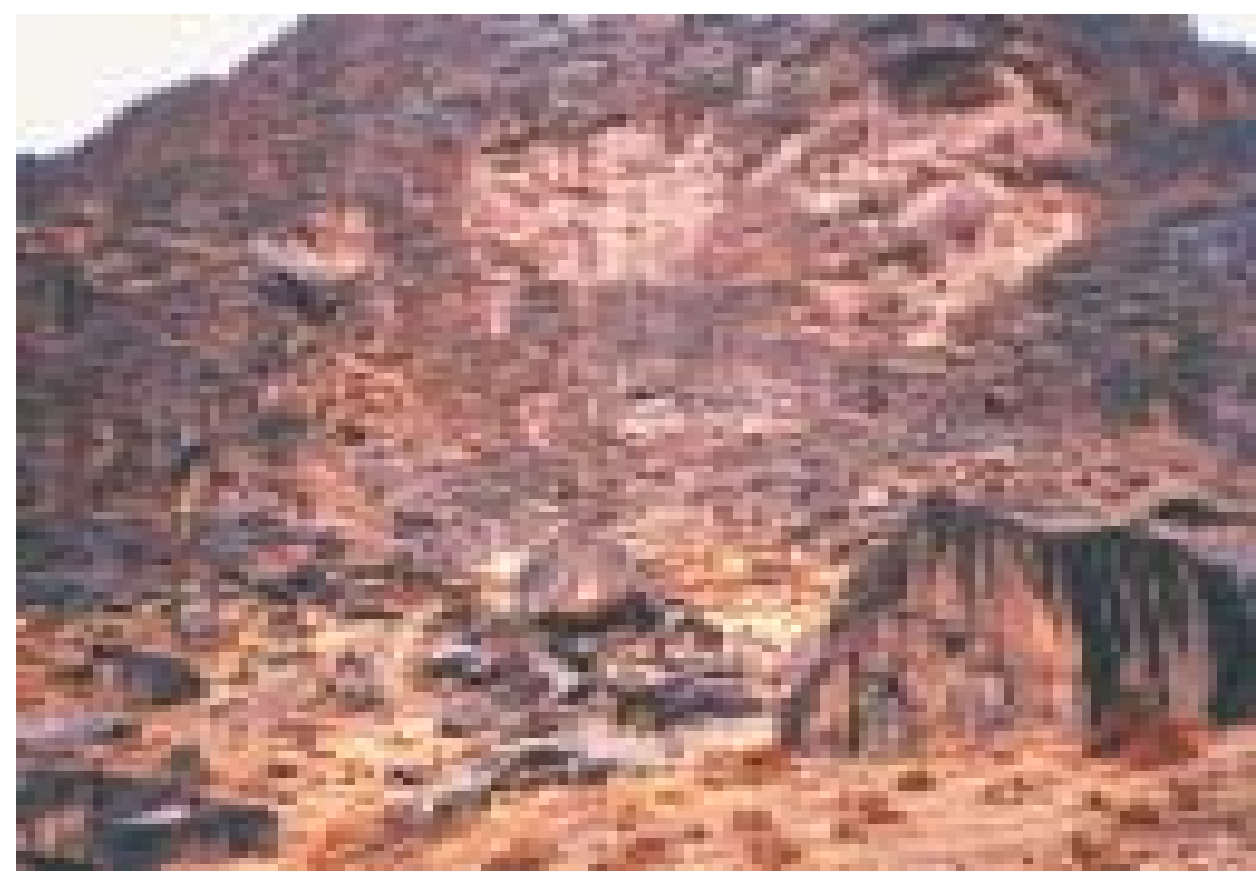

Fig. 3: A view of Jurassic-Cretaceous limestone (North West). 


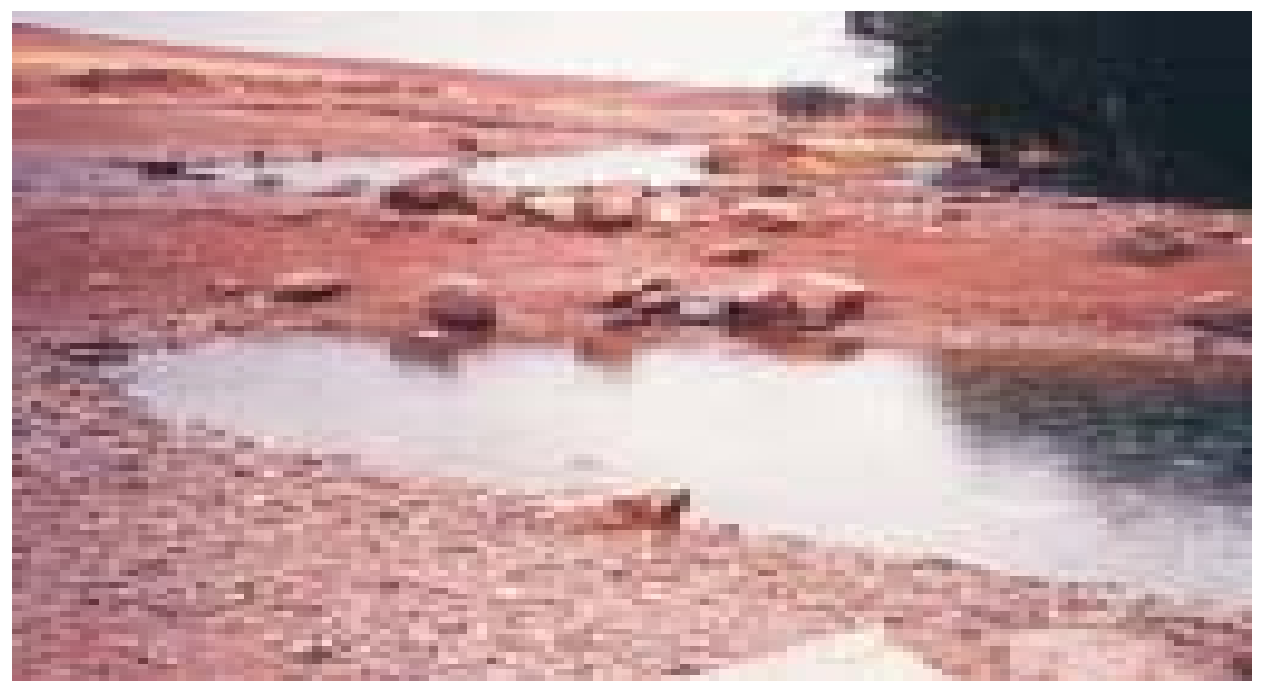

Fig. 4: A view of Zaz spring.

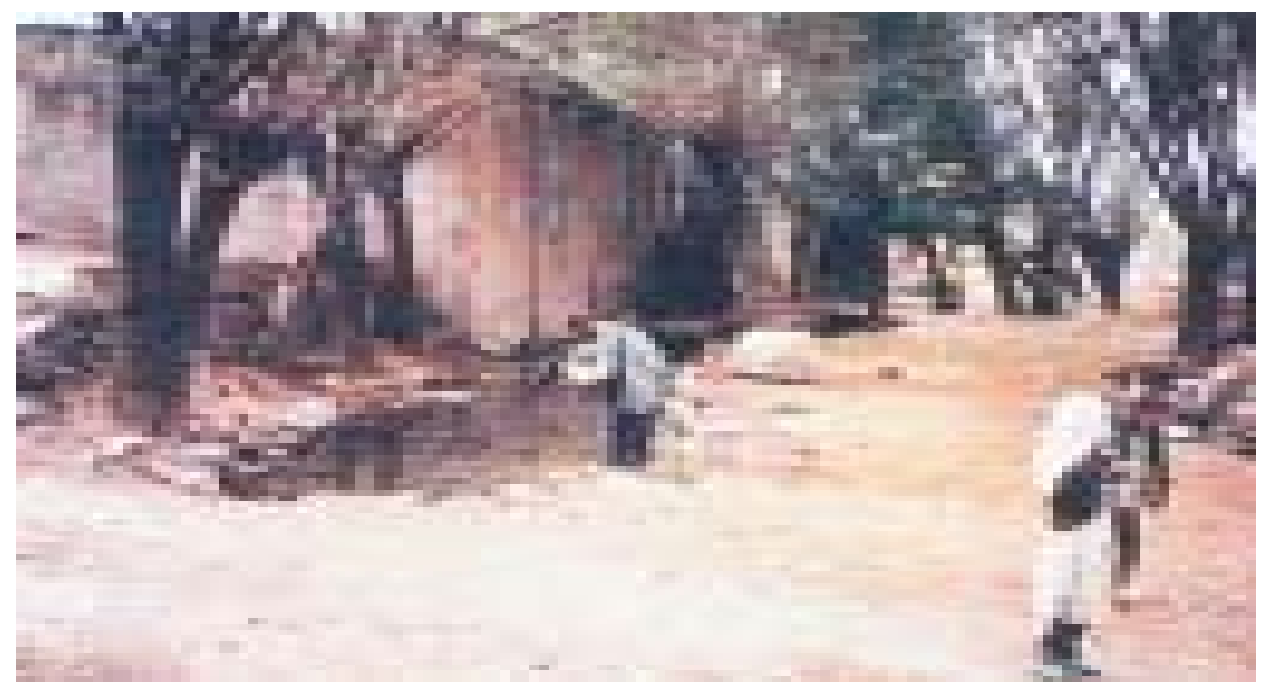

Fig.5: A view of Honam spring. 

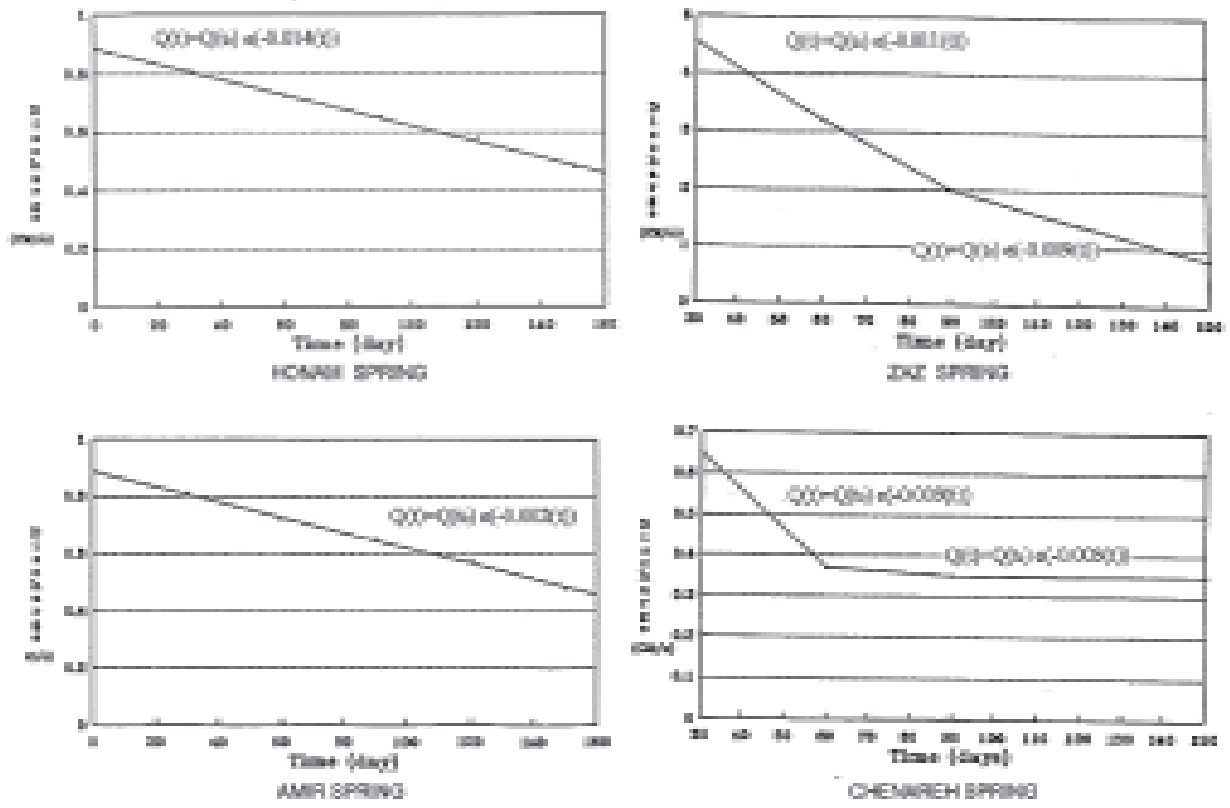

Fig. 6: The recession coefficients and the volume of the springs.

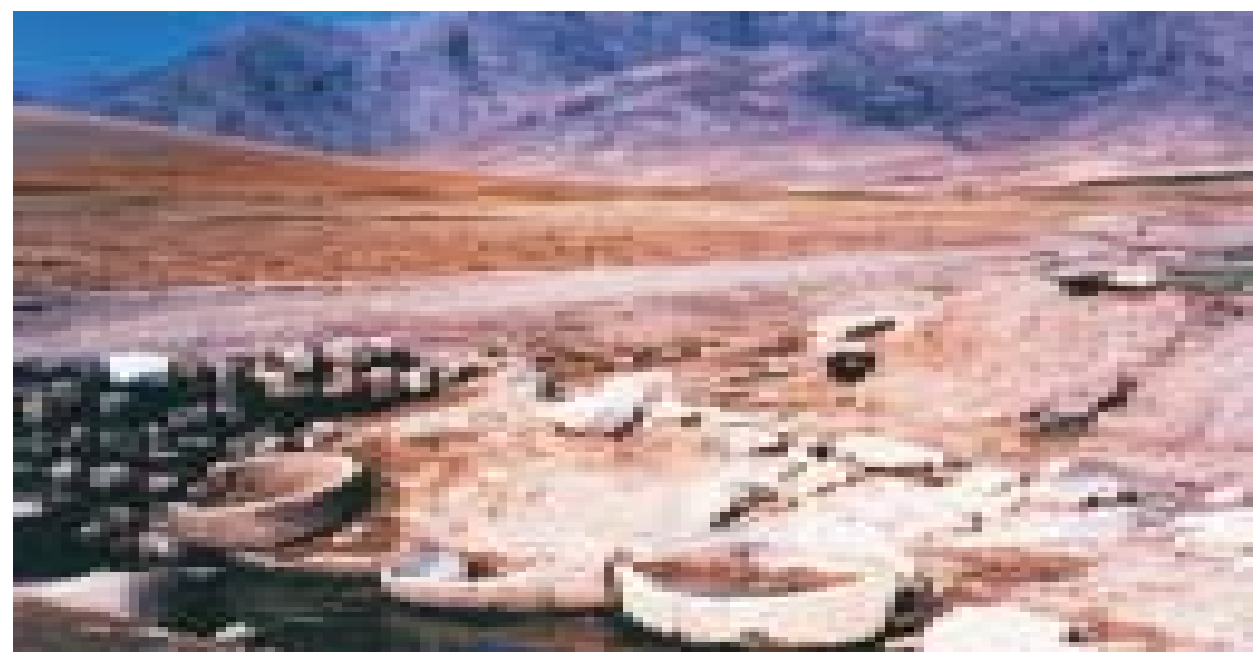

Fig. 7: A view of Qanat. 


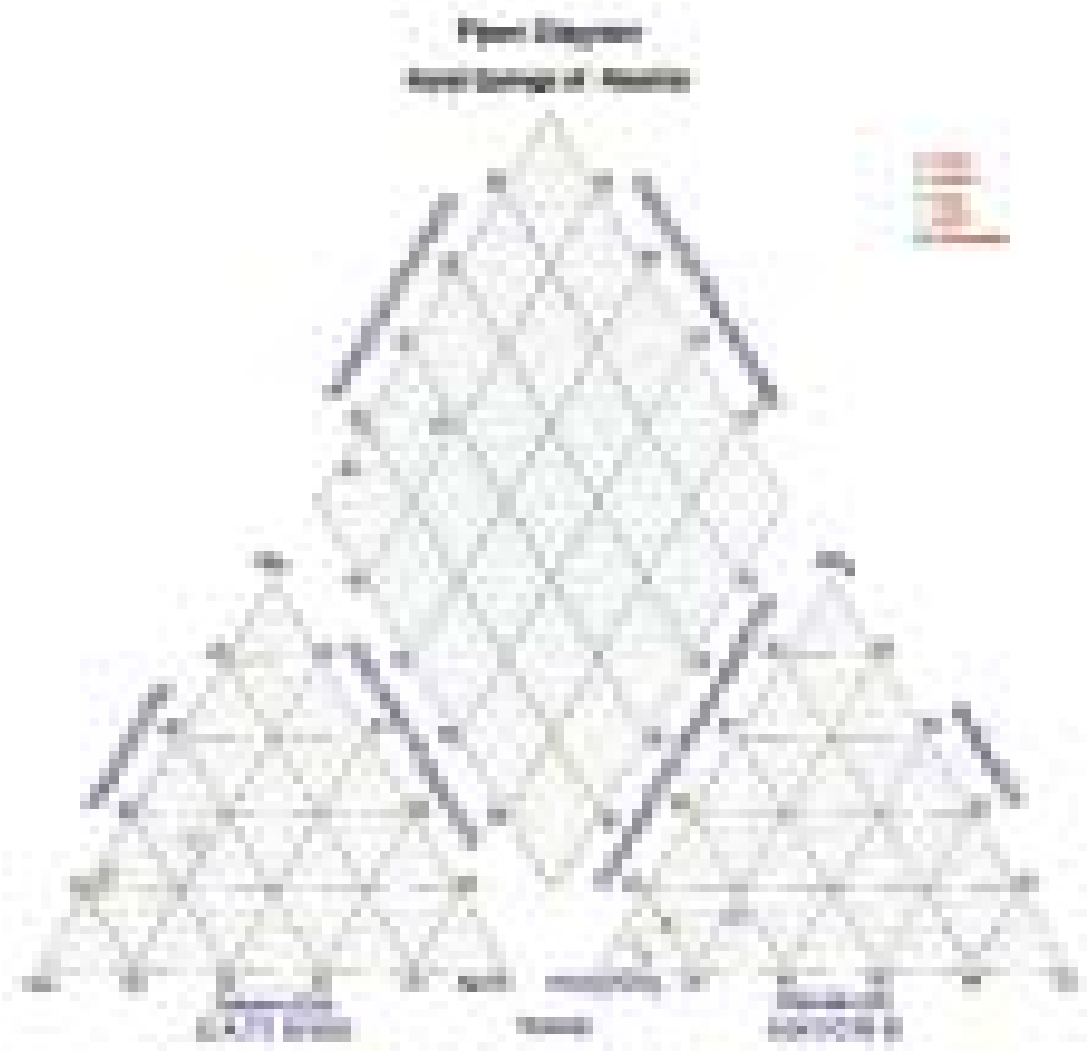

Fig.8: Piper Digram of the karstic springs.

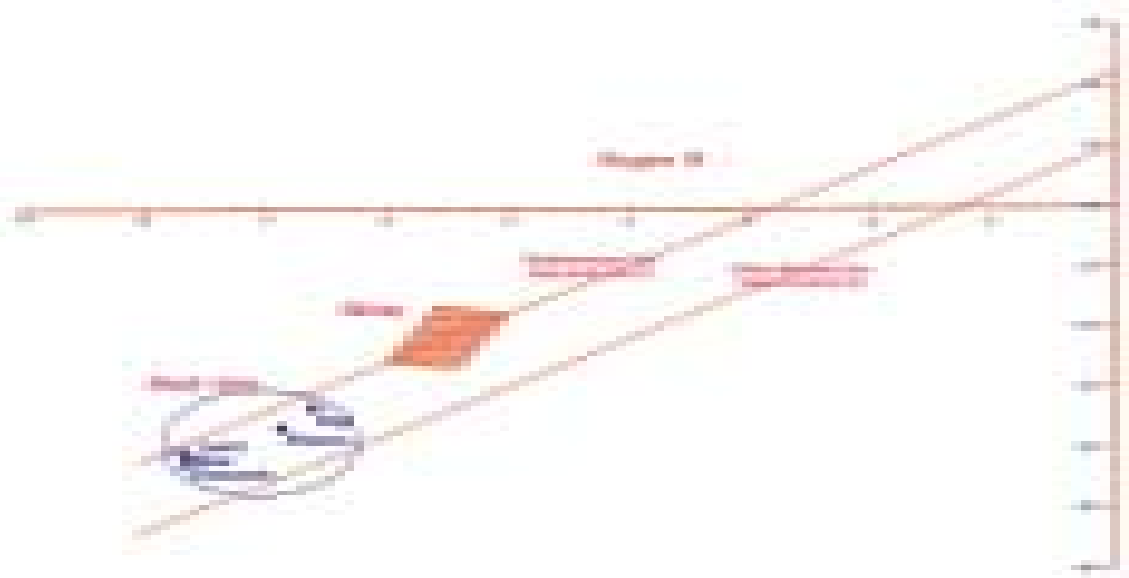

Fig. 9: Relation of Oxygen-18 and Deuetrium of the Karstic springs of the study area. 


\section{WELLS}

The alluvial deposits mostly consists of cobble, sand and clay. The thickness of the deposits varies between 25 and 150 meters. There are 210 wells with discharge from 20 to 65 liters per second. The total discharge of the wells is 38.5 million $\mathrm{m}^{3} / \mathrm{y}$. The direction of groundwater flow is northwest to southeast.

\section{KARSTIC SPRINGS}

In the area under study there are 5 karstic springs named as Chenareh, Amir, Zaz, Honam and Papi that emerge along the faults and the joints. The faults can be classified as thrust and normal ones. The situation of the springs are shown in figure 1. The Chenareh, Amir and Zaz springs emerge from the Jurassic-Cretaceous rocks.

\section{ZAZ SPRING}

The spring shows high variation of discharge. At times when there is low precipitation the spring becomes completely dry. Figure 4 shows view of the spring. The maximum disharge is $4.7 \mathrm{~m}^{3} / \mathrm{s}$. The main source of the spring has a doline shape with a depth of about 3 meters.

\section{CHENAREH SPRING}

The spring is situated in the north-west of the area. The maximum discharge is $0.67 \mathrm{~m}^{3} / \mathrm{s}$.

\section{AMIR SPRING}

The spring is situated in thr northern part of the plain and discharges from the J-C limestone. The maximum discharge is $0.8 \mathrm{~m}^{3} / \mathrm{s}$.

\section{HONAM SPRING}

This spring emerges from the marly limestone of Eocene age in the eastern part of the area . The Honam river receive its water from this spring. The maximum discharge of the spring is $0.8 \mathrm{~m}^{3} / \mathrm{s}$. Figure 5 shows the location of the spring.

\section{PAPI SPRING}

The spring emerges from the marly limestone near the south of the plain. The maximum discharge is $0.25 \mathrm{~m}^{3} / \mathrm{s}$.

\section{RECESSION CURVE OF THE KARSTIC SPRINGS}

The recession curve of the springs show that the springs have different recession coefficients with different flow regimes. Figure 6 shows the recession coefficients set. On the basis of the curves, the Honam and Amir Springs have one type of flow regime. 


\section{QANATS}

There are two qanats in the north west of the area which are recharged by the Jurassic Cretaceous limestone. The total discharge of the qanats is 1.58 million $\mathrm{m}^{3} / \mathrm{y}$. Figure 7 shows a view of one of them.

\section{HYDROCHEMICAL STUDY}

Inorder to specify the type of the water samples, the Piper diagram has been drawn (Figure 8). The figure shows that the water samples of the karstic springs are of calcium bicarbonate type.

\section{ENVIRONMENTAL ISOTOPES}

The analyses of the water samples of the karstic springs for oxygen-18 and Deuterium was carried out by the International Atomic Energy Agency ( IAEA), Vienna in 1993.

Unfortunately due to the lack of financial support, the analyses of the environmental isotopes was not carried out for a long duration.

Based on the relation of Oxygen-18 and Deuetrium, the samples can be classified into two groups with different recharge areas. The higher concentration of Oxygen-18 and Deuetrium of the springs indicate that these springs are recharged at a lower elevation than the other springs. The relation is shown in figure 9. In this figure, water samples of Shiraz (South west of the Iran) have been correlated with the karstic springs (west of Iran).

\section{CONCLUSION}

- The development of the fractures and the joints are the main avenue for the springs.

- The type of the water is of calcium bicabonate.

- Study of the recession curve coefficients indicate that the springs have different flow regimes

- The higher concentration of oxygen-18 and Deuetrium of the springs of Honam and Papi indicate that these springs are recharged at a lower elevation than the others.

\section{ACKNOWLEDGEMENT}

The author thanks Professor Gunnay for his fruitful guidance. He also wishes to thank Mr. B. Ebrahimi for helping in drawing the figures. 


\section{REFERENCES}

Ahmadipour, M., 1993; Hydrogeological investigations of Alashtar Basin (West of Iran).

Hem, M., 1970: Study and interpretation of chemical charactristics of natural water USGS., Water supply paper no. 1430

Ahmadipour, M., 1999: Karst terraines in Iran - examples from Lorestan. Acta Carsologica 28/2, 213-224.

Ahmadipour, M. \& B. Ebrahimi, 2000; Groundwater modeling of Alashtar plain.

Käss, Werner, 1998: Tracing Technique in Geohydrology.- Updated translation of Geohydrologische Markierungstechnik, 1992, XV + 1-581, Rotterdam/Brookfield

Davis G. H., 1996: Structural geology of rocks and regions. 